\title{
Biogas Production from Vegetables and Fruit Wastes Using Anaerobic Floating Bioreactor
}

\author{
Soeprijanto Soeprijanto*, Anfi Reynikha Fatullah, Sashi Agustina, Dyah Firdha Amalia, Alif Adi Kaisar \\ Department of Industrial Chemical Engineering, Faculty of Vocational Studies, \\ Institut Teknologi Sepuluh Nopember (ITS), Surabaya 60111, Indonesia
}

\section{Artikel histori : \\ Diterima 11 September 2020 \\ Diterima dalam revisi 01 Oktober 2020 Diterima 30 Oktober 2020 Online 31 Oktober 2020}

\begin{abstract}
ABSTRAK: Markets and supermarkets are one of the pillars of the country's economy, besides that, they are also the biggest contributors to vegetable and fruit waste which can cause various environmental problems. Therefore, the abundance of vegetable and fruit waste produced by markets and supermarkets can be utilized as environmentally friendly alternative energy, namely biogas. This study aimed to determine the effect of organic loading rate (OLR) on biogas production and gas composition in a continuous anaerobic floating bioreactor using mixed vegetable and fruit waste. A 40-1 anaerobic floating bioreactor was utilized and the hydraulic retention time was 10 days; one $\mathrm{kg}$ of vegetable and fruit wastes at a 1:1 mass ratio was added with water to 41 and introduced during 25 days; the daily biogas production was collected in a floating drum and measured as volume. The maximum biogas yield was 0.0452 $\mathrm{m}^{3} / \mathrm{kg}$, achieved using the OLR of $0.0125 \mathrm{~kg} / \mathrm{lday}$. The use of OLR of $0.0250,0.0375$ and $0.0500 \mathrm{~kg} / \mathrm{l} . \mathrm{d}$ reached biogas yields of $0.0435,0.0282$, and $0.0163 \mathrm{~m}^{3} / \mathrm{kg}$, respectively. The composition of the maximum biogas yield was $68.17 \% \mathrm{CH}_{4}, 19.34 \% \mathrm{CO}_{2}, 1.85 \% \mathrm{H}_{2} \mathrm{~S}$, and $0.64 \% \mathrm{NH}_{3}$.
\end{abstract}

Keywords: Biogas; bioreactor; HRT; OLR; vegetable waste; fruit waste. prices and is difficult to reach by most Indonesians. One way to save fuel is to look for alternative and renewable energy sources. Alternative energy sources in Indonesia are quite available, such as solar energy, wind energy, and water. So far, the most widely used energy is hydropower, however, the development of other alternative energy sources is still open. The alternative energy that is likely to be developed is biogas energy. Biogas technology is one of the appropriate technologies for treating waste to produce energy that utilizes microorganisms that are available in nature to treat various organic wastes placed in airtight spaces. Biogas is one of the effective and efficient solutions for providing alternative energy sources. Biogas is produced from the fermentation process of organic materials assisted by anaerobic bacteria in an environment without involving oxygen, biogas is dominated by methane gas $(55 \%-75 \%)$, carbon dioxide $(25 \%-45 \%)$, and several other gases in higher amounts small (Soeprijanto, 2019; Zhang et al., 2014).

Fruit and vegetable waste is a problematic waste as a result of generating huge amounts, the broad range of environmental impacts on causing, for instance, water and air pollution, and also greenhouse gas emissions (Schanes et al., 2018). A landfill is the most used disposal method for fruit and vegetable wastes that contribute to the release of high organic loading leachates and greenhouse gases.

Anaerobic digestion is one of the biological treatments for organic waste that is receiving increasing attention due to its high value for waste (Bong et al., 2018). The waste contains high biodegradability and high volatile solids (Edwiges et al., 2020; Fisgativa et al., 2016). The main advantage of the anaerobic digestion process is the 
production of biogas for renewable energy, but also promotes nutrient recovery in the digestate, which can be used as a biofertilizer (Koido et al., 2018). This method has been successfully applied in reducing the volume of waste that enters landfills, thereby decreasing methane emissions produced by decay (Mata-Alvarez et al., 2000; ForsterCarneiro et al., 2008; Bouallagui et al., 2009).

Anaerobic digestion of vegetable waste was carried out by Velmurugan and Ramanujam (2011). They showed that the average methane content in the biogas was $65 \%$ and the methane yield was $0.387 \mathrm{l} \mathrm{CH}_{4} / \mathrm{g} \mathrm{VS}$ for the selected types of wastes in mesophilic conditions using a fed-batch laboratory-scale reactor.

Methane gas has been widely recognized as an environmentally friendly material because it can burn completely so that it does not produce smoke which adversely affects air quality. Because of its nature, methane gas is a gas with high economic value and can be used for various purposes ranging from cooking to driving a steam turbine power plant. The methane content in biogas is a component that can be an alternative fuel as an alternative energy source for fossil fuels. While other components such as $\mathrm{CO}_{2}$ and $\mathrm{N}_{2}$ are impurities that have harmful properties. The complexity of the biogas content, making the use of this alternative fuel as a substitute for fossil fuel in energy conversion machines still requires a deeper study. Especially, how the influence of impurities, especially $\mathrm{CO}_{2}$ on the characteristics of biogas combustion.

Production of alternative biogas energy is relatively easy, where the organic wastes can be used as the raw materials by using biogas digester unit so that the process of integrating organic waste runs quickly, then the organic waste is chopped up before being put into the reactor (Soeprijanto, 2019). This biogas energy is very appropriate to be developed in Indonesia because many Indonesians work as farmers. Besides, biogas energy can be produced by utilizing vegetable and fruit wastes from markets and supermarkets (Bouallagui et al., 2005; Soeprijanto et al., 2019). The market as one of the backbones of a country's economy is also the biggest contributor to vegetable and fruit wastes. These piles of vegetable and fruit waste are rarely used by the community because they are no longer suitable for animal feed (Huang et al., 2016). Usually, vegetable and fruit waste are only left alone, causing odors that can interfere with environmental cleanliness and health. Also, vegetable and fruit waste have long been a serious problem, such as causing odors that interfere with breathing and affect health. Organic waste has the potential to be used as material for biogas production, but it is not yet widely used. Even so far it has caused pollution problems that have an impact on environmental health. According to Soeprijanto et al. (2019), the advantage of making biogas from municipal solid waste is that there is no need to add nutrients because the amount of $\mathrm{N}$ and $\mathrm{P}$ in municipal solid waste in this research is a very large vegetable waste (Wang et al., 2012).

In this study, fruit and vegetable waste was used as feedstock to produce biogas using a floating anaerobic bioreactor. This bioreactor has an advantage not only to convert agricultural waste to biogas but also to collect the biogas produced.

The purpose of his study was to determine the effect of variations in the loading rate of vegetable and fruit waste on biogas production using anaerobic floating bioreactors.

\section{Materials and methods}

\subsection{Materials}

Cow dung was obtained from a Slaughterhouse at Penggirian Surabaya. Vegetable and fruit waste in the form of apples, bananas, papaya, cabbage, mustard greens, and tomatoes were obtained from Supermarkets at Surabaya.

\subsection{Methods}

In this study, fruit and vegetable wastes (VFW) mixed with cow dung were used as substrates for biogas production in a 401 cylindrical floating anaerobic digester. The VFW was weighed as much as $1 \mathrm{~kg}$ with a ratio of fruit and vegetable of $1: 1(\mathrm{w} / \mathrm{w})$ (a ratio of vegetable wastes of cabbage $1 / 3$, chicory $1 / 3$, and tomatoes $1 / 3$ and a ratio of fruit wastes of papaya $1 / 3$, apples $1 / 3$, and bananas peels $1 / 3$ ). The anaerobic floating bioreactor (Figure 1) was conducted in a continuous mode with a feeding volume of 41 per day to achieve a hydraulic retention time (HRT) of 10 days. The biogas production was collected in a floating drum and monitored daily for up to 25 days by observing the level changes on the floating drum. The gas analysis was carried out using gas chromatography to determine the content of methane, carbon dioxide, ammonia, and hydrogen sulfide.

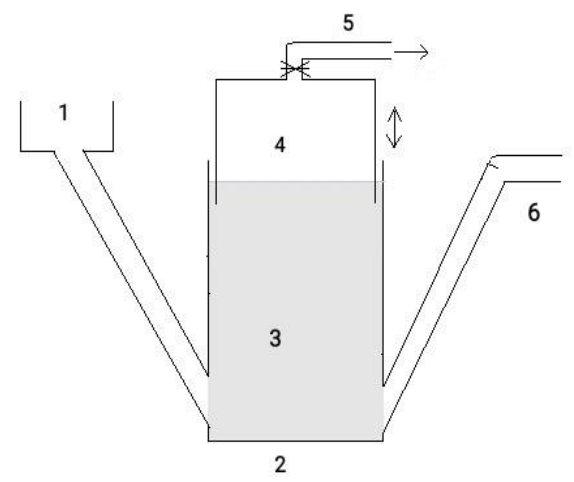

Figure 1. Schematic diagram of the digester. ( $1=$ influent feeding; 2 = floating anaerobic digester; $3=$ slurry; 4 = gas in floating drum; 5 = gas pipe; $6=$ effluent)

\section{Results and discussion}

The content of vegetable and fruit waste is one of the important parameters in the formation of biogas. The analysis results are shown in Table1. 
Table 1. Analysis results of vegetable and fruit waste samples.

\begin{tabular}{cc}
\hline Parameter & Percentage \\
\hline Cellulose & $28 \%$ \\
Hemicellulose & $14 \%$ \\
Lignin & $5 \%$ \\
Protein & $4.08 \%$ \\
TS & $70.3 \%$ \\
VS & $27.6 \%$ \\
\hline
\end{tabular}

\subsection{Biogas production}

The continuous anaerobic digestion was carried out in this study. Organic loading rate (OLR) is one of the parameters that determine the formation of biogas. Figure 2 shows there is a correlation between daily biogas production with OLR that has been carried out for 25 days of operation. The results depicted during the stable operation, the mean daily biogas productions were $4240 \mathrm{ml} /$ day with OLR of 0.0125 $\mathrm{kg} / \mathrm{l}$.day, $8120 \mathrm{ml} /$ day with OLR of $0.0250 \mathrm{~kg} / \mathrm{l}$.day, 8220 $\mathrm{ml} /$ day with 0.0375 of $\mathrm{kg} / \mathrm{l}$.day, and $6160 \mathrm{ml}$ with OLR of $0.050 \mathrm{~kg} / \mathrm{l} . \mathrm{d}$, respectively (Figure 3 ). Of the four OLRs, the maximum daily biogas production was found to be in the OLR of $0.0375 \mathrm{~kg} / \mathrm{l}$.day, with an average volume of 8220 $\mathrm{ml} /$ day.

This result is consistent with the other authors (Al Mamun, 2014; Babaee and Shayegan, 2011; Deublein, 2008; Dhanalakshmi et al., 2012; Dhanalakshmi and Ramanujam, 2012) which stated that the greater the amount of substrate contained in the waste, thus the organic burden that must be described in microbes that is also greater. This is due to the increasingly limited number of active decomposing microorganisms, thus the ability to degrade the substrate is increasingly limited (Soeprijanto, 2019). Biogas production depends on the volatile organic solid load that was fed per day to the digestion. This means that the amount of biogas produced depended on the number of substrates. Organic loading rate (OLR) that is too high can produce a saturated state where volatile fatty acids increase (Soeprijanto, 2019). Biogas production will decrease and the proportion of $\mathrm{CO}_{2}$ increases. OLR is an important factor for the survival of microorganisms and their optimum activity; and is a very important control parameter in a continuous system. If the higher OLR that is fed will require more bacteria, this causes the system to not work properly, if not properly prepared. Also, an overload of organic matter can cause a significant increase in volatile fatty acids which cause acidification in the medium and will ultimately end the inactivity of all bacteria due to low $\mathrm{pH}$ which causes system failure (Soeprijanto, 2019). There are also fluctuations in biogas production, which is an increase and decrease that is not following the literature this is because the anaerobic process is highly dependent on the activity of microorganisms that are very susceptible to fluctuations. Air contamination causes biogas-producing bacteria which are obligate anaerobic bacteria will experience growth inhibition and even die (Deublein, 2008). Al Mamun and Torii (2014) showed the daily biogas production varied from a minimum of $0.8 \mathrm{l} / \mathrm{day}$ and a maximum of $39 \mathrm{~L} /$ day for $\mathrm{CW}: \mathrm{VW}$ : FW (0.5:1.0:1.5) ratio and $\mathrm{CW}: \mathrm{VW}$ : FW (1.0:1.0:1.0) ratio, respectively. The anaerobic digestion of a mixture of vegetable wastes was carried by Dhanalakshmi et al. (2012). They operated a single-stage mesophilic anaerobic reactor in a 21 with the HRT of 25 days for two OLR of 0.25 and $0.5 \mathrm{gVS} / \mathrm{l}$.d. The results indicated the mean biogas production was 0.150 and 0.300 1/day, respectively. Dhanalakshmi and Ramanujam (2012) studied in a batch anaerobic reactor using vegetable waste. The organic loading rate (OLR) used in the experiment was in the range of $0.06-0.47 \mathrm{~g} \mathrm{VS}$. They found the maximum cumulative gas production was 3764 $\mathrm{ml}$ for $0.26 \mathrm{~g} \mathrm{VS} \mathrm{OLR}$. Babaee and Shayegan (2011) experimented to evaluate the production of biogas from vegetable wastes using an anaerobic digester. They showed the biogas production was in the range of $0.12-0.4 \mathrm{~m}^{3} / \mathrm{kg}$, the methane content was in the range of $49.7-64 \%$ and The methane yield was $0.25 \mathrm{~m}^{3} / \mathrm{kgVS}$ with the reduction of $88 \% \mathrm{VS}$ at OLR of $1.4 \mathrm{~kg} \mathrm{VS} / \mathrm{m}^{3}$.day.

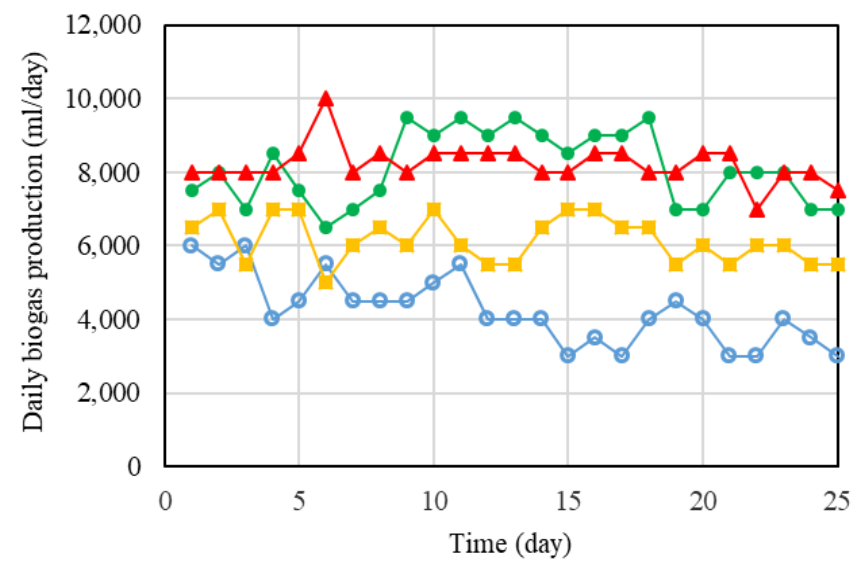

Figure 2. Effect of OLR on biogas production $(O=$ OLR of $0.0125 \mathrm{~kg} / \mathrm{l} . \mathrm{d} ; \boldsymbol{\square}=0.0250 \mathrm{~kg} / \mathrm{l} . \mathrm{d} ; \boldsymbol{\Lambda}=0.0375 \mathrm{~kg} / \mathrm{l} . \mathrm{d} ; \bullet=$ $0.050 \mathrm{~kg} / \mathrm{l} . \mathrm{d}$.)

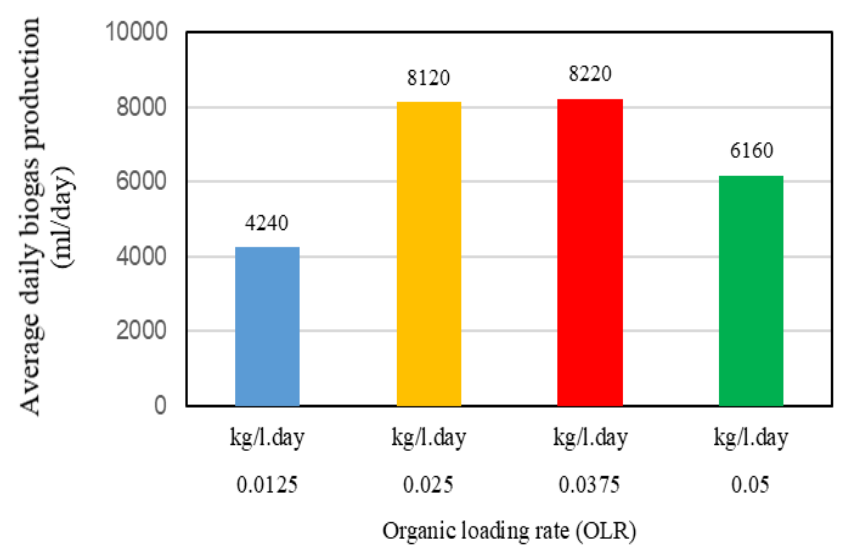

Figure 3. Effect of OLR on average daily biogas production.

\subsection{Cumulative biogas production}

Figure 4 shows the effect of OLR on cumulative biogas production. The results showed that there was an increase 
in the cumulative value of biogas production for 25 days. Biogas produced every day had a different volume composition, with the highest biogas production achieved at OLR of $0.0250 \mathrm{~kg} / \mathrm{l}$.d, was $205,500 \mathrm{ml}(1,059 \mathrm{ml} / \mathrm{g} \mathrm{VS})$, then followed by OLR of $0.0250 \mathrm{~kg} / \mathrm{l}$.d was $203,000 \mathrm{ml}$, OLR of $0.050 \mathrm{~kg} / \mathrm{l} . \mathrm{d}$ was $154,000 \mathrm{ml}(793.70 \mathrm{ml} / \mathrm{g} \mathrm{VS})$, and OLR of $0.0125 \mathrm{~kg} / \mathrm{l} . \mathrm{d}$ was $106,000 \mathrm{ml}(546.31 \mathrm{ml} / \mathrm{g} \mathrm{VS})$, respectively. However, when compared to the other authors, these studies had the highest values, as most of the results found by the other authors conducted on a batch mode. Forster-Carneiro et al. (2008) reported biogas production of $180 \mathrm{ml} / \mathrm{g}$ VS for the mono-digestion of source sorted OFMSW. Scano et al. (2014) and Lin et al. (2011) found the mean yields of methane of $430 \mathrm{ml} / \mathrm{g} \mathrm{VS}$ and $420 \mathrm{~m} / \mathrm{g}$ VS, respectively, for VFW digestion. Pavi et al. (2017) showed the average cumulative biogas and methane yield in the co-digestion for OFMSW was 493.8 $\mathrm{ml} / \mathrm{g} \mathrm{VS}$ and in the mono-digestion was $396.6 \mathrm{ml} / \mathrm{g} \mathrm{VS}$, respectively.

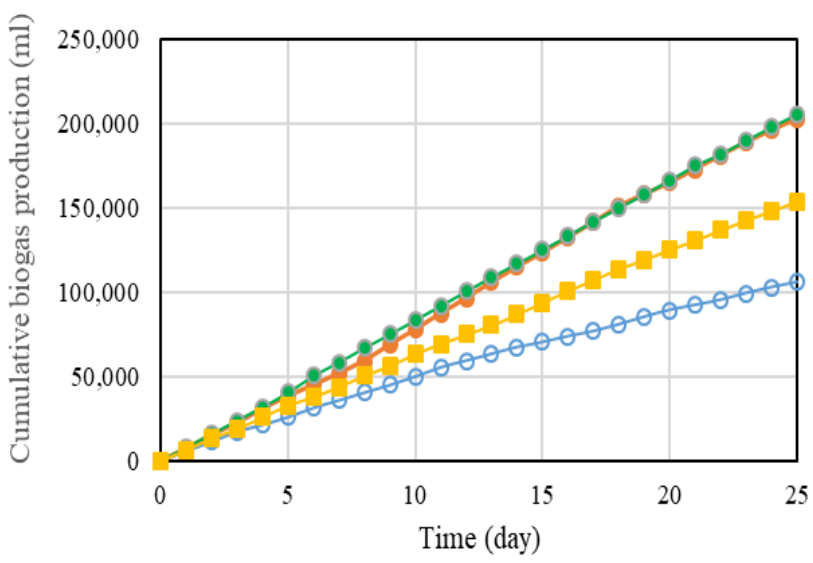

Figure 4. Effect of OLR on cumulative biogas production. ( $\mathrm{o}=$ OLR of $0.0125 \mathrm{~kg} / \mathrm{l} . \mathrm{d} ; \boldsymbol{\square}=0.0250 \mathrm{~kg} / \mathrm{l} . \mathrm{d} ; \boldsymbol{\Delta}=0.0375$

$$
\mathrm{kg} / \mathrm{l} . \mathrm{d} ; \bullet=0.050 \mathrm{~kg} / \mathrm{l} . \mathrm{d} \text {.) }
$$

\subsection{The content of biogas production}

Figure 5 shows the relationship between OLR and the resulting biogas composition. The results indicated that with an OLR value of $0.0125 \mathrm{~kg} / \mathrm{l} . \mathrm{d}$ the content of methane was $68.17 \%$, OLR of $0.0250 \mathrm{~kg} / \mathrm{l}$.d produced $67.91 \%$, OLR of $0.0375 \mathrm{~kg} / \mathrm{l}$.d produced $69.29 \%$, and OLR of 0.050 $\mathrm{kg} / \mathrm{l} . \mathrm{d}$ produced $68.58 \%$, respectively. There was no significant difference in the composition results of each OLR. Similar results were also found by other authors. Borowski (2015) reported the contents of methane in the range of 55- 60\% for the mono-digestion of OFMSW and the range of $58-66 \%$ for the co-digestion of OFMSW and sewage sludge. Bouallagui et al. (2003) showed methane contents of $64 \%$ in biogas for anaerobic digestion of VFW, while Scano et al. (2014) reported mean methane contents of $75 \%$ in short time lapses. However, Li et al. (2011) reported lower average methane contents in the range of $53.7 \%$ and $63.8 \%$.

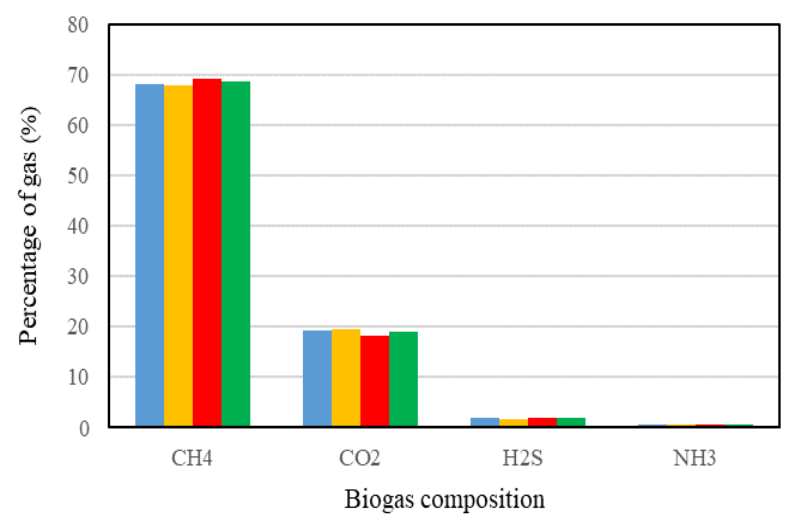

Figure 5. Effect of organic loading rate on biogas composition ( $\mathrm{O}=\mathrm{OLR}$ of $0.0125 \mathrm{~kg} / \mathrm{l} . \mathrm{d}$; $\boldsymbol{\square}=0.0250 \mathrm{~kg} / \mathrm{l} . \mathrm{d}$;

$$
\mathbf{\Delta}=0.0375 \mathrm{~kg} / \mathrm{l} . \mathrm{d} ; \bullet=0.050 \mathrm{~kg} / \mathrm{l} . \mathrm{d} \text {. })
$$

\subsection{The yield of biogas production}

The effect of OLR on biogas production is shown in Figures 6 and 7. The results showed the biogas yields obtained were $0.0452,0.0435,0.0282$, and $0.0163 \mathrm{~m}^{3} / \mathrm{kg}$ at OLR of $0.0125,0.0250,0.0375$ and $0.0500 \mathrm{~kg} / \mathrm{l} . \mathrm{d}$, respectively. In this study, the highest biogas yield was $0.0452 \mathrm{~m}^{3} / \mathrm{kg}$, reaching an OLR of $0.0125 \mathrm{~kg} / \mathrm{l}$.d. The use of OLR of $0.0250,0.0375$ and $0.0500 \mathrm{~kg} / \mathrm{l} . \mathrm{d}$ reached biogas yields of $0.0435,0.0282$, and $0.0163 \mathrm{~m}^{3} / \mathrm{kg}$, respectively.

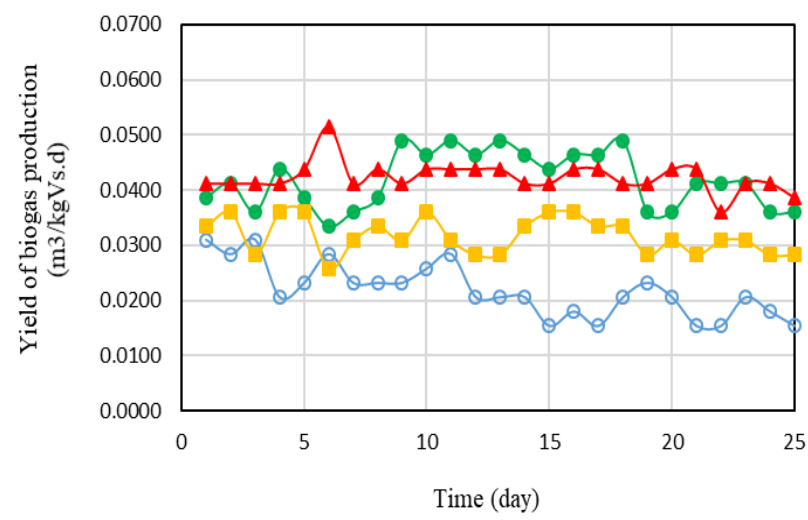

Figure 6. Effect of organic loading rate on yield of biogas production. $(\mathrm{O}=\mathrm{OLR}$ of $0.0125 \mathrm{~kg} / \mathrm{l} . \mathrm{d} ; \mathbf{\square}=0.0250 \mathrm{~kg} / \mathrm{l}$.d; $\boldsymbol{\Delta}=0.0375 \mathrm{~kg} / \mathrm{l} . \mathrm{d} ; \bullet=0.050 \mathrm{~kg} / \mathrm{l} . \mathrm{d}$.)

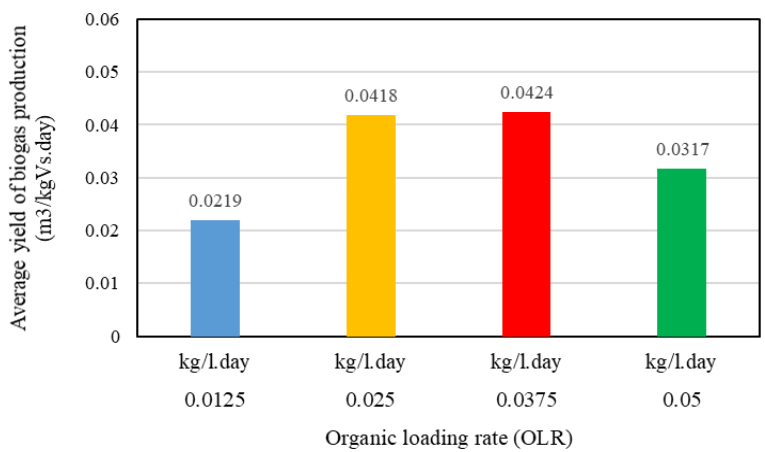

Figure 7. The correlation between OLR and an average yield of biogas production. 


\section{Conclusion}

It was concluded in this study that the vegetable and fruit waste had a potential for biogas production and the by-product of the anaerobic digestion is useful for fertilizer. The floating anaerobic bioreactor is not only a treatment of agricultural waste to produce biogas but also to have a function of biogas store. The maximum biogas yield was $0.0452 \mathrm{~m}^{3} / \mathrm{kg}$, achieved using the OLR of $0.0125 \mathrm{~kg} / \mathrm{l}$.day, and had a composition of $68.17 \% \mathrm{CH}_{4}, 19.34 \% \mathrm{CO}_{2}$, $1.85 \% \mathrm{H}_{2} \mathrm{~S}$, and $0.64 \% \mathrm{NH}_{3}$.

In future work, to obtain the increased biogas production will be improved by hydrothermal pretreatment before feeding to the anaerobic digestion.

\section{Acknowledgment}

The authors would like to thank the Department of Industrial Chemical Engineering to support a Laboratory Facility.

\section{List of Notation}

$$
\begin{aligned}
& C_{s p l}=\text { sample concentration }[\mathrm{g} / \mathrm{l}] \\
& C W=\text { cow dung waste }[\mathrm{g}] \\
& F W=\text { fruit wastes }[\mathrm{g}] \\
& V_{s p l}=\text { sample volume }[\mathrm{ml}] \\
& C_{s t d}=\text { standard concentration }[\mathrm{g} / \mathrm{l}] \\
& V_{s t d}=\text { standard volume }[\mathrm{ml}] \\
& V W=\text { vegetable wastes }[\mathrm{g}] \\
& P \quad=\text { pressure }[\text { atm }] \\
& T \quad=\text { temperature }\left[{ }^{\circ} \mathrm{C}\right] \\
& t \quad=\text { time [second, hour] } \\
& V \quad=\text { volume }[\mathrm{ml}, \mathrm{l}]
\end{aligned}
$$

\section{References}

Al Mamun, M.R. and Torii, S., 2014. Production of biomethane from cafeteria, vegetable and fruit wastes by anaerobic Co-Digestion Process. Journal of Advanced Agricultural Technologies Vol. 1. No. 2, 9499.

Babaee, A. and Shayegan, J., 2011. Effect of organic loading rates (OLR) on production of methane from anaerobic digestion of vegetables waste. Proceedings of World Renewable Energy Congress-2011 Sweden, 411417

Bong, C.P.C., Lim, L.Y., Lee, C.T., Kleme, J.J., Ho, C.S., Ho, W.S., 2018. The characterisation and treatment of food waste for improvement of biogas production during anaerobic digestion - a review. J. Clean. Prod. Vol. 172, 1545-1558. https:/doi.org/10.1016/j.jclepro.2017.10.199

Borowski, S., 2015. Co-digestion of the hydromechanically separated organic fraction of municipal solid waste with sewage sludge. J. Environ. Manage. Vol. 147, 87-94.

Bouallagui, H., Ben, Cheikh, R., Marouani, L., Hamdi, M., 2003. Mesophilic biogas production from fruit and vegetable waste in tubular digester. Bioresour. Technol. Vol. 86, 85-89.

Bouallagui, H., Touhami, Y., Ben Cheikh, R., Hamdia, M., 2005. Bioreactor performance in anaerobic digestion of fruit and vegetable wastes: review. Process Biochem. Vol. 40, 989-995.

Bouallagui, H., Lahdheb, H., Ben Romdan, E., Rachdi, B., Hamdi, M., 2009. Improvement of fruit and vegetable waste anaerobic digestion performance and stability with co-substrates addition. J. Environ. Manage. Vol. 90, 1844-1849.

Carneiro, T.F., Pérez, M., Romero, L.I., 2008. Anaerobic digestion of municipal solid wastes: Dry thermophilic performance. Bioresour. Technol. Vol. 99, 8180-8184

Deublein, Dieter and Angelika Steinhauser 2008. Biogas from Waste and Renewable Resources. Wiley-VHC: Jerman.

Dhanalakshmi S. V., Srinivasan S.V., Kayalvizhi R. and Bhuvaneswari R., 2012. Studies on Conversion of Carbohydratecontent in the Mixture of Vegetable Wastes into Biogas in a Single Stage Anaerobic Reactor. Res. J. Chem. Sci. Vol. 2. No. 6, 66-71.

Dhanalakshmi, S.V. and Ramanujam, R.A., 2012. Biogas generation in a vegetable waste anaerobic digester : An analytical approach. Res. J. Recent Sci. Vol. 1. No. 3, 41-47.

Edwiges, T., Mantovani Frare, L., Lima Alino, J.H., Mi Triolo, J., Flotats, X., Silva de Mendonça Costa, M.S., 2020. Methane potential of fruit and vegetable waste: an evaluation of the semi-continuous anaerobic mono digestion. Environ. Technol. Vol.41 No.7

Fisgativa, H., Tremier, A., Dabert, P., 2016. Characterizing the variability of food waste quality: a need for efficient valorization through anaerobic digestion. Waste Manag. Vol. 50, 264-274. https://doi.org/10.1016/j.wasman.2016.01.041.

Forster-Carneiro, T., Perez, M., Romero, L.I., 2008. Influence of total solid and inoculum contents on performance of anaerobic reactors treating food waste. Bioresour. Technol.Vol. 99, 6763-6770.

Huang, X., Yun, S., Zhu, J., Du, T., Zhang, C., Li, X., 2016. Mesophilic anaerobic codigestion of aloe peel waste with dairy manure in the batch digester: focusing on mixing ratios and digestate stability. Bioresour. Technol. Vol. 218, 62-68.

Koido, K., Takeuchi, H., Hasegawa, T., 2018. Life cycle environmental and economic analysis of regional- scale food-waste biogas production with digestate nutrient management for fig fertilization. J. Clean. Prod. Vol. 190, 552-562. https://doi.org/10.1016/j.jclepro.2018.04.165.

Li, Y., Park, S.Y., Zhu, J., 2011. Solid-state anaerobic digestion for methane production from organic waste. Renewable Sustainable Energy Rev. Vol. 15, 821-826.

Mata-Alvarez, J., Mace, S., Llabrés, P., 2000. Anaerobic digestion of organic solid wastes. An overview of research achievements and perspectives. Bioresour. Technol. Vol. 74, 3-16. 
Pavi, S., Kramer, L.E., Gomes, L.P., Miranda, L.A.S. 2017. Biogas production from co-digestion of organic fraction of municipal solid waste and fruit and vegetable waste. Bioresour. Technol. Vol. 228, 362-367

Scano, E.A., Asquer, C., Pistis, A., Ortu, L., Demontis, V., Cocco, D., 2014. Biogas from anaerobic digestion of fruit and vegetable wastes: experimental results on pilot-scale and preliminary performance evaluation of a full-scale power plant. Energy Convers. Manage. Vol. 77, 22-30.

Schanes, K., Dobernig, K., G€ozet, B., 2018. Food waste matters - a systematic review of household food waste practices and their policy implications. J. Clean. Prod. Vol. 182, 978-991.

Soeprijanto, Juzma Ilmahur Mawaddah, Rexy Widya Tauchid, Anfi Reynikha Fatullah, Sashi Agustina, 2019. Biogas production from canteen wastes using a vertical anaerobic digester. Prosiding Seminar Nasional Teknik Kimia "Kejuangan", 25 April 2019.

Soeprijanto, 2019. Biogas sebagai energi terbarukan (Biogas as Renewable Energy). Surabaya ITS Press.

Velmurugan, B. and Ramanujam, R. A., 2011. Anaerobic Digestion of Vegetable Wastes for Biogas Production in a Fed-Batch Reactor, Int. J. Emerg. Sci., Vol. 1. No.3, 478-486.

Wang, X., Yang, G., Feng, Y., Ren, G., Han, X., 2012. Optimizing feeding composition and carbon-nitrogen ratios for improved methane yield during anaerobic codigestion of dairy, chicken manure and wheat straw. Bioresour. Technol. Vol. 120, 78-83.

Zhang, C., Su, H., Baeyens, J., Tan, T., 2014. Reviewing the anaerobic digestion of food waste for biogas production. Renewable Sustainable Energy Rev. Vol. $38,383-392$. 